\title{
Statyba
}

\section{CURVATURE ANALYSIS OF HIGH STRENGTH CONCRETE BEAMS}

\section{G. Kaklauskas PhD \& M. Hallgren PhD}

To cite this article: G. Kaklauskas PhD \& M. Hallgren PhD (1999) CURVATURE ANALYSIS OF HIGH STRENGTH CONCRETE BEAMS, Statyba, 5:6, 357-363, DOI: 10.1080/13921525.1999.10531490

To link to this article: https://doi.org/10.1080/13921525.1999.10531490

曲 Published online: 26 Jul 2012.

Submit your article to this journal $\pi$

III Article views: 132 


\section{CURVATURE ANALYSIS OF HIGH STRENGTH CONCRETE BEAMS}

\section{G. Kaklauskas and M. Hallgren}

\section{Introduction}

Concrete technology has developed rapidly during last decades. It is now quite common to use concrete with a compressive strength of $100 \mathrm{MPa}$ or higher. High strength concrete seems to be an appropriate material to achieve higher, longer or more slender structures and to gain cost savings. However, current design codes for concrete structures are mainly based on tests where the concrete strengths have been below $60 \mathrm{MPa}$.

The shape of the stress-strain curve obtained from uniaxial compression tests of plain specimens is similar for concrete of normal, medium and high strength as shown in Fig 1. A high-strength concrete behaves in a linear fashion to a relatively higher stress level and has a higher strain at maximum stress than the low-strength concrete. On the descending portion of the stress-strain curve, higher strength concrete tends to behave in a more brittle manner, the stress dropping more sharply than it does for concrete with lower strength.

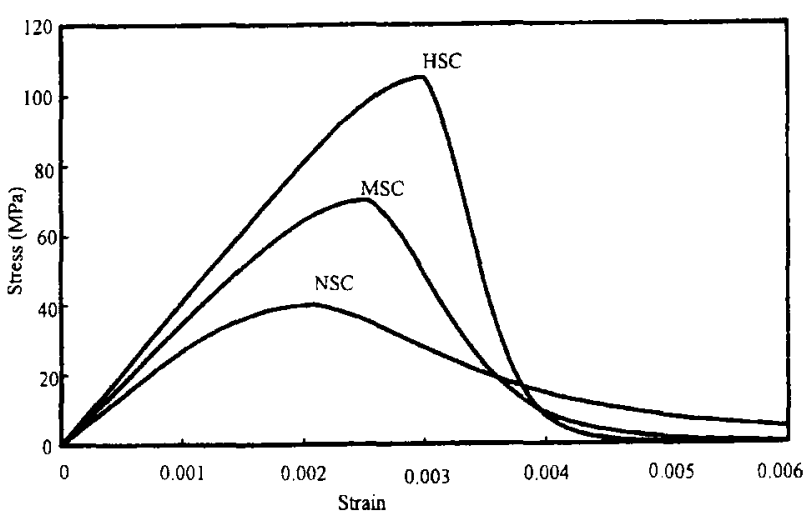

Fig 1. Typical stress-strain curves for normal (NSC), medium (MSC) and high strength concrete (HSC)

A number of complete stress-strain curves, both for normal and high strength concrete has been proposed. Mansur et al. [1] modified a complete stress-strain relationship of the serpentine curve proposed by Carreira and Chu [2]:

$$
\sigma_{c}=\frac{f_{c} k_{1} \beta_{c}\left(\varepsilon_{c} / \varepsilon_{0}\right)}{k_{1} \beta_{c}-1+\left(\varepsilon_{c} / \varepsilon_{0}\right)^{k_{2} \beta_{c}}},
$$

where

$$
\begin{gathered}
f_{c}=0.94 f_{c}^{\prime}, \quad \varepsilon_{0}=0.0005\left(f_{c}\right)^{0.35}, k_{1}=\left(40 / f_{c}\right)^{2}, \\
k_{2}=\left(40 / f_{c}^{\prime}\right)^{1.3}, \quad \beta_{c}=1 /\left(1-f_{c} / \varepsilon_{0} E_{c}\right) \\
E_{c}=10300\left(f_{c}\right)^{0.33}
\end{gathered}
$$

Here $\sigma_{c}$ and $\varepsilon_{c}$ are respectively the stress and strain of compressive concrete; $f_{c}$ and $\varepsilon_{0}$ are respectively the peak stress and strain for $100 \times 100 \times 200 \mathrm{~mm}$ prism; $k_{1}$ and $k_{2}$ are correction factors; $\beta_{c}$ is a material parameter depending on the shape of the stress-strain diagram; and $E_{c}$ is the initial tangent modulus

Thorenfeldt et al [3] proposed a similar expression to $\mathrm{Eq} \perp$ for both normal and high strength concrete with the only difference of assuming $k_{1}=1$.

Recently a new constitutive relationship for cracked tensile concrete based on smeared crack approach has been proposed [4] for deformational analysis of flexural reinforced concrete members. The relationship has been developed on a basis of a number of stress-strain curves for tensile concrete [4-6] obtained from beam tests reported in literature. Accuracy of the proposed constitutive relationship has been investigated [7] by calculating deflections for a large number of experimental reinforced concrete beams with moderate and small reinforcement ratios reported by several investigators.

The paper is aimed at investigating deformational behaviour of high strength concrete beams subjected to short-term bending. The present work includes both experimentation and analysis. The experimental part has involved a set of load test data for flexural high strength concrete elements. In the analytical contribution, comparison of experimental curvatures with curvatures predicted by four methods is carried out. 


\section{Tests of reinforced concrete beams from high strength concrete}

General

The second author at the Royal Institute of Technology, Sweden, conducted flexural tests of 26 reinforced concrete beams of normal and high strength concrete [8]. The compressive cube $(150 \mathrm{~mm})$ strength of concrete ranged from about 40 to $100 \mathrm{MPa}$. The beams were simply supported and subjected to short-term four-point bending. Present research deploys experimental data of 26 beams divided into three series: B90, B91 and B92. All the beams had a rectangular cross-section and were singly reinforced in the pure bending zone. Beams of series $\mathrm{B} 90$ were nominally $4.0 \mathrm{~m}$ long, $140 \mathrm{~mm}$ high and $150 \mathrm{~mm}$ wide (in the pure bending zone) while the corresponding characteristics for beams of series B91 and B92 were 5.2 $\mathrm{m}, 150 \mathrm{~mm}$ and $180 \mathrm{~mm}$. Measured cross-section dimensions and material strengths of the test beams are presented in Table 1.

\section{Material properties}

Concrete mix details are given in Table 2. The beams were cured covered with wet burlap sacks during the first five days and then in indoor climate in the laboratory with a relative humidity of about $70 \%$ and temperature of $20^{\circ} \mathrm{C}$. Compressive strength of concrete (Table 1) was determined by tests on cylinders ( $300 \mathrm{~mm}$ height and 150 $\mathrm{mm}$ diameter) and cubes (150 $\mathrm{mm}$ ). Number and diameter of deformed reinforcement bars as well as their yield stress are indicated in Table 1.

\section{Testing arrangements}

The test beams were supported on hinged roller supports which enabled free rotation and free horizontal displacement of the beams. The load was applied to the test beam with a servohydraulic actuator and transferred to the two loading points by a steel beam.

The longitudinal concrete strains in the mid section of the test beams were measured by five electrical resistance strain gauges glued to the beam surface. One of these gauges was placed centrally on the compressive surface and the other four at different levels on one side of the test beams with the extreme gauge distanced at 55 $\mathrm{mm}$ from the top. The strain in the tension reinforcement was measured in one bar in the mid section of the test beams. The bar was provided with two gauges glued to opposite sides. All gauges were of trade mark Showa and the lengths of the gauges for measuring concrete and steel strains were 30 and $8 \mathrm{~mm}$, respectively.

The loading was controlled with a MTS 458.20 control console. The load was applied at a deformation rate of about $0.1 \mathrm{~mm} / \mathrm{s}$, measured on the movement of the piston rod, and in steps of $2.0 \mathrm{kN}$ until the first crack was visually observed on the vertical side surfaces of the test beam. After the appearance of the first crack, the loading steps were increased to $4.0 \mathrm{kN}$. Between the loading steps, the piston rod was locked for about two minutes, during which the crack pattern was inspected and recorded. When the yield load of the beam was reached, the deformation rate was increased and the beam was loaded continuously until complete failure. The experimental results were presented in terms of moment-curvature $(M-\kappa)$, diagrams for 26 test beams [8].

\section{Strain and curvature analysis technique}

The present curvature analysis method is based on classical principles of strength of materials extended to layered approach and use of full material diagrams. It is based on the following assumptions of behaviour of flexural reinforced concrete members: 1) the hypothesis of plane sections of beam bending and the resulting linear distribution of strain within the depth of the beam section is adopted; 2) perfect bond between reinforcement and concrete is assumed; 3 ) the constitutive model is based on the smeared crack approach, ie stresses and strains are averaged over representative lengths to span several cracks.

According to the layered approach, the beam's crosssection is divided into a number of horizontal layers corresponding to either concrete or reinforcement. Each layer may have different material properties assumed to be constant over the layer thickness. Thickness of the reinforcement layer is taken from the condition of the equivalent area. For reinforcement material idealisation, a bilinear, trilinear or more complex stress-strain relationship can be adopted. The stress-strain relationship for the compressive concrete has been assumed according to Eqs (1) and (2) assuming $k_{1}=1$. The present analysis employs a stress-strain relationship for tensile concrete proposed by the first author [4]. The descending part of the relationship shown in Fig 2 has the expression: 


$$
\sigma_{t}=0.625 f_{t}^{\prime}\left(1-\frac{\overline{\varepsilon_{t}}}{\beta}-\frac{1+0.6 \beta}{\beta \overline{\varepsilon_{t}}}\right)
$$

where

$$
\begin{gathered}
\overline{\varepsilon_{t}}=\frac{\varepsilon_{t}}{\varepsilon_{t}^{\prime}} ; \quad \varepsilon_{t}^{\prime}=\frac{f_{t}^{\prime}}{E_{c}}, \\
\beta=32.8-27.6 p+7.12 p^{2}, \\
\beta=5, \text { if } \quad p \geq 2 \%,
\end{gathered}
$$

where $p$ is reinforcement percentage. Tensile strength of concrete was taken as

$$
f_{t}^{\prime}=0.23 \sqrt[3]{R_{15}^{2}}[\mathrm{MPa}],
$$

where $R_{15}$ is $150 \mathrm{~mm}$ cube compression strength.

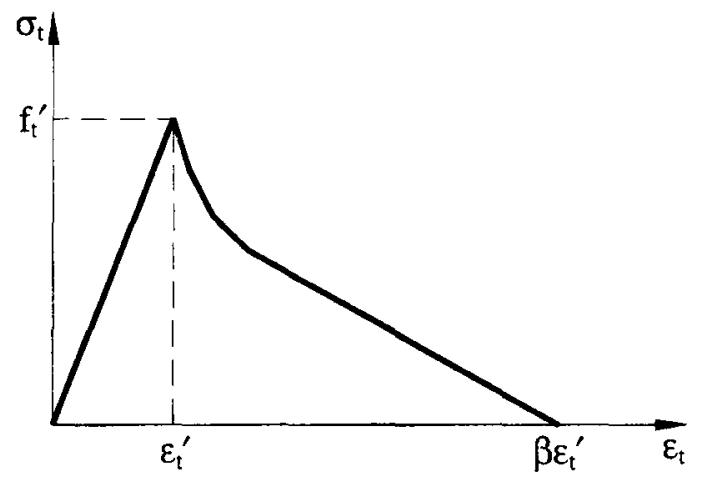

Fig 2. A stress-strain relationship for tensile concrete

A computer program has been developed for assessment of average stress and strain state at any point of the beam as well as for calculation of curvatures. For a given external moment, the computation is performed in iterations by the following steps:

1. In the first iteration, elastic material properties are assumed for all the layers.

2. Geometrical characteristics are calculated for the transformed cross-section.

3. Curvature of the section is calculated from the expression:

$$
\kappa=\frac{M}{(E I)_{t r}},
$$

where $(E I)_{t r}$ is the flexural stiffness of the transformed cross-section.

4. Longitudinal strain at every layer $i$ is taken as

$$
\varepsilon_{i}=\kappa y_{i},
$$

where $y_{i}$ is the distance of $i$ layer from the centroid of the transformed cross-section.
5. For the assumed material diagrams (eg, Fig 2), stress $\sigma_{i}$ corresponding to strain $\varepsilon_{i}$ is obtained. A secant deformation modulus $\bar{E}_{i}=\sigma_{i} / \varepsilon_{i}$ is determined.

6. Values of the obtained secant deformation modulus $\overline{E_{i}}$ for every layer are compared with the previously assumed or computed ones. If the agreement is not within the assumed error limits, a new iteration is started from step 2.

7. After convergation of deformation modulus $\bar{E}_{i}$ for all the layers, final values of strains, stresses and curvature are computed.

\section{Comparison of curvatures assessed by different methods with test results}

This section compares predicted and experimental curvatures of 26 beams described in section 2 (Table 1). Curvatures were assessed not only by the method discussed above, but also by ACI [9] Eurocode [10], and Russian Code [9]methods.

Curvatures for all the beams were calculated at five moment levels, ie $0.4,0.55,0.6,0.7$ and 0.8 of $M_{u}$ which is the experimental ultimate moment. The experimental (dashed lines) and computed by the present analysis method (solid lines) moment-curvature diagrams for the three series are presented in Fig 3. Although good agreement has been achieved for most of the beams, some tendency of underestimation of curvatures with increasing discrepancy at higher moments can be noted. The reason for that could be due to the following: 1) the computation has not assessed any plastic strains of reinforcement; 2) since most of the specimens were highly reinforced members, numerical curvature results corresponding to higher loads were very sensitive to variation of such factors as concrete strength and the shape of the descending branch of the stress-strain relationship for compressive concrete. Previous analysis [7] has shown that for moderately and lightly reinforced members neither concrete strength nor the shape of the descending branch of the compressive stress-strain relationship have significant influence on numerical results of deformations whereas the main factors are the modulus of elasticity of concrete as well as the stress-strain relationship for tensile concrete. For visualisation purposes, relative curvatures, $\kappa_{t h} / \kappa_{\text {exp }}$, versus relative moments are presented graphically in Fig. 4 where data points corresponding to different series are marked differently. 
Momentai [kNm]
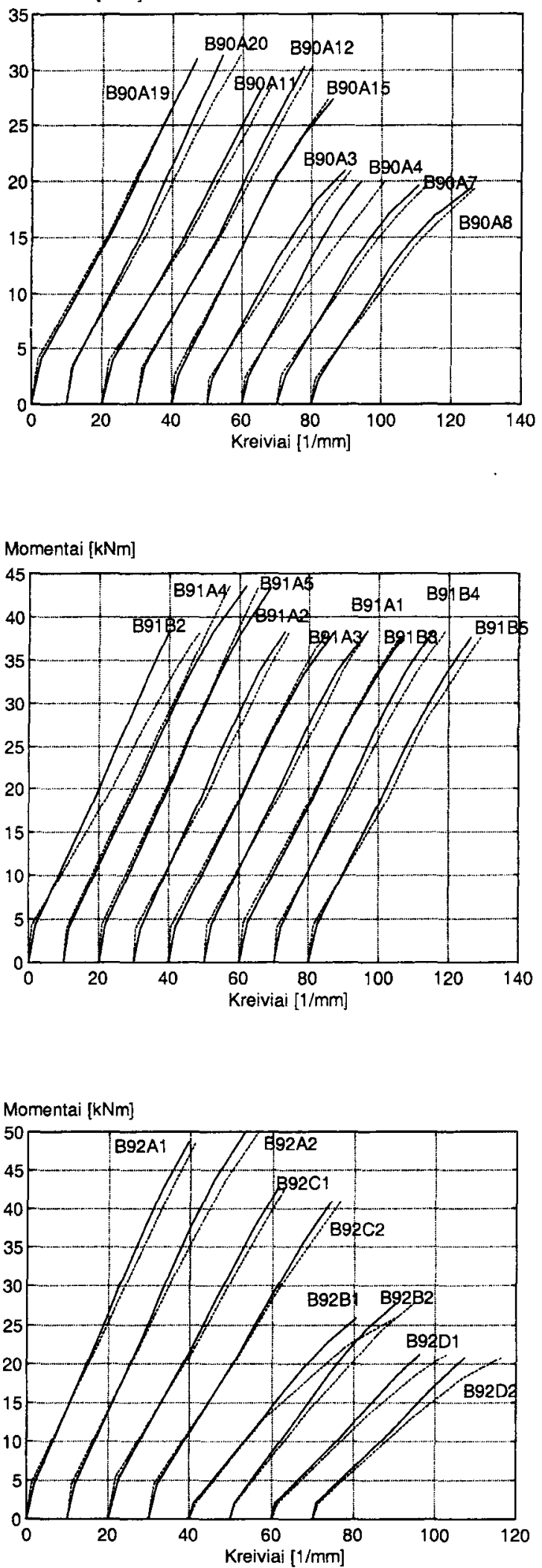

Fig 3. Moment-curvature diagrams - computer, --.---.-- - experimental

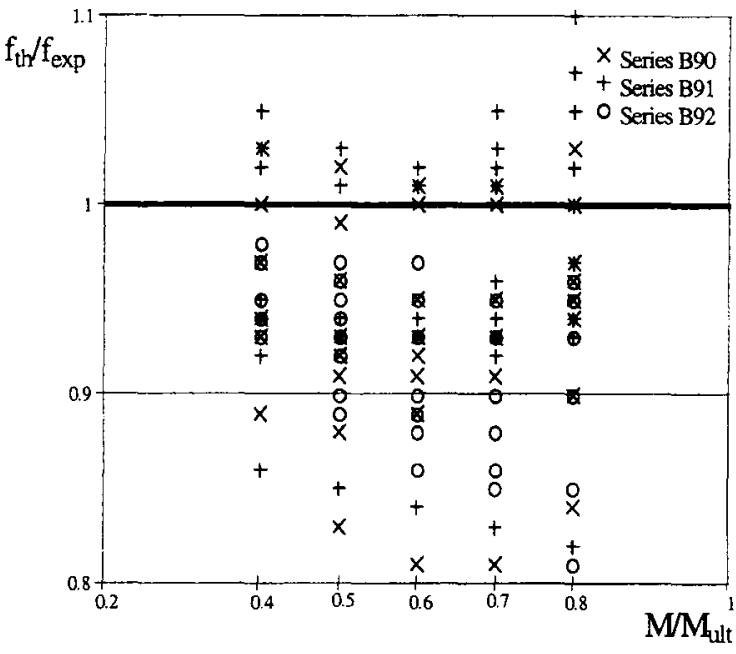

Fig 4. Present analysis predictions: relative deflections versus relative moments

Accuracy of predictions has been assessed using basic statistical parameters such as mean value and standard deviation calculated for relative curvatures. These statistical parameters assessed for predictions by the method of present analysis and ACI [9], Eurocode [10], and Russian Code [11] methods are presented Table 3. It contains the statistical parameters not only for the total data, but also for moment levels corresponding to $0.4,0.6$, and 0.8 of $M_{u}$

An excellent agreement for the total data has been achieved for the present analysis, Eurocode and ACI methods with standard deviations for relative curvatures, $\kappa_{\text {th }} / \kappa_{\exp }$, not exceeding $7.5 \%$ (Table 3 ). Even better results have been obtained for the moment level $0.4 M_{u}$, but greater variation corresponded to $0.8 M_{u}$. A tendency of the reduced mean value and its deviation from unity with increasing moments is clear for the ACI and Eurocode methods. Although predictions by the Russian Code method lead to a slightly greater standard deviation, the method gave a reasonable mean value.

Finally, it should be noted that better curvature predictions achieved in the present analysis by all the methods in comparison to the previous analysis [7] of reinforced concrete beams with low and moderate reinforcement ratios can be explained not only by high accuracy of the testing, but also by relatively insignificant role of tensile concrete due to high reinforcement ratio. When the influence of the tensile concrete (its strength) as a highly dispersed value is excluded, flexural deformability is mostly dependent on far more reliable characteristics such as modulus of elasticity of steel and concrete. 
Table 1. Main characteristics of test beams

\begin{tabular}{|c|c|c|c|c|c|c|c|c|c|c|}
\hline \multirow[t]{2}{*}{ No } & \multirow[t]{2}{*}{ Beam } & \multirow{2}{*}{$\begin{array}{c}\text { Depth } \\
\text { [mm] } \\
h\end{array}$} & \multirow{2}{*}{$\begin{array}{c}\text { Width } \\
{[\mathrm{mm}]} \\
b\end{array}$} & \multirow{2}{*}{$\begin{array}{c}\text { Effective } \\
\text { depth } \\
\text { [mm] } \\
d\end{array}$} & \multirow{2}{*}{$\begin{array}{c}150 \mathrm{~mm} \\
\text { cube } \\
\text { strength } \\
{[\mathrm{MPa}]} \\
R_{15}\end{array}$} & \multirow{2}{*}{$\begin{array}{c}\text { Cylinder } \\
\text { strength } \\
\text { [MPa }] \\
f_{c}^{\prime}\end{array}$} & \multicolumn{3}{|c|}{ Tensile steel } & \multirow{2}{*}{$\begin{array}{c}\text { Reinforcement } \\
\text { ratio } \\
{[\%]} \\
P\end{array}$} \\
\hline & & & & & & & $\begin{array}{c}\text { No and diame- } \\
\text { ter of bars } \\
{[\mathrm{mm}]}\end{array}$ & $\begin{array}{c}\text { Section } \\
\text { area } A_{s} \\
\times 10^{-4}\left[\mathrm{~m}^{2}\right]\end{array}$ & $\begin{array}{c}\text { Yield } \\
\text { strength } f_{s y} \\
{[\mathrm{MPa}]}\end{array}$ & \\
\hline \multicolumn{11}{|c|}{ Series B90 } \\
\hline 1 & B90A3 & 145 & 151 & 112 & 41.0 & 32.8 & $3 \varnothing 16$ & 603 & 636 & 3.6 \\
\hline 2 & B90A4 & 145 & 155 & 113 & 41.0 & 32.8 & $3 \varnothing 16$ & 603 & 636 & 3.4 \\
\hline 3 & B90A7 & 139 & 159 & 108 & 38.6 & 31.1 & $3 \varnothing 16$ & 603 & 636 & 3.5 \\
\hline 4 & B90A8 & 140 & 157 & 105 & 38.6 & 31.1 & $3 \varnothing 16$ & 603 & 636 & 3.7 \\
\hline 5 & B90A11 & 139 & 153 & 105 & 97.0 & 86.2 & $3 \varnothing 16$ & 603 & 645 & 3.8 \\
\hline 6 & $\mathrm{~B} 90 \mathrm{~A} 12$ & 140 & 155 & 106 & 97.0 & 86.2 & 3016 & 603 & 645 & 3.7 \\
\hline 7 & B90A15 & 142 & 164 & 113 & 51.5 & 44.9 & $3 \varnothing 16$ & 603 & 645 & 3.3 \\
\hline 8 & B90A 19 & 140 & 157 & 107 & 100.5 & 84.6 & $3 \varnothing 16$ & 603 & 645 & 3.6 \\
\hline 9 & $\mathrm{~B} 90 \mathrm{~A} 20$ & 141 & 156 & 110 & 100.5 & 84.6 & $3 \varnothing 16$ & 603 & 645 & 3.5 \\
\hline \multicolumn{11}{|c|}{ Series B91 } \\
\hline 10 & B91A1 & 151 & 180 & 108 & 72.4 & 65.7 & $2 \varnothing 25$ & 981 & 623 & 5.0 \\
\hline 11 & B91A2 & 150 & 180 & 110 & 73.4 & 61.8 & $2 \varnothing 25$ & 981 & 623 & 5.0 \\
\hline 12 & $\mathrm{~B} 91 \mathrm{~A} 3$ & 150.5 & 180 & 107 & 73.4 & 61.8 & $2 \varnothing 25$ & 981 & 623 & 5.0 \\
\hline 13 & B91A4 & 151 & 182 & 108 & 80.4 & 69.1 & $2 \varnothing 25$ & 981 & 623 & 5.0 \\
\hline 14 & B91A5 & 152 & 180.5 & 110 & 80.4 & 69.1 & $2 \varnothing 25$ & 981 & 623 & 4.9 \\
\hline 15 & B91B2 & 152 & 183.5 & 115 & 83.0 & 60.8 & $4 \varnothing 16$ & 804 & 647 & 3.8 \\
\hline 16 & B91B3 & 150 & 182 & 111 & 72.4 & 65.7 & $4 \varnothing 16$ & 804 & 647 & 4.0 \\
\hline 17 & B91B4 & 150.5 & 181 & 114 & 69.7 & 58.3 & $4 \varnothing 16$ & 804 & 647 & 3.9 \\
\hline 18 & B91B5 & 150 & 183.5 & 112 & 69.7 & 58.3 & $4 \varnothing 16$ & 804 & 647 & 3.9 \\
\hline \multicolumn{11}{|c|}{ Series B92 } \\
\hline 19 & B92A1 & 154 & 176 & 112 & 90.4 & 76.7 & 3025 & 1473 & 623 & 7.5 \\
\hline 20 & B92A2 & 151 & 185 & 109 & 90.4 & 76.7 & 3025 & 1473 & 623 & 7.3 \\
\hline 21 & B92B 1 & 153 & 180 & 113 & 47.5 & 42.1 & $3 \varnothing 16$ & 603 & 631 & 3.0 \\
\hline 22 & B92B2 & 156 & 180 & 117 & 47.5 & 42.1 & $3 \varnothing 16$ & 603 & 631 & 2.9 \\
\hline 23 & B92C1 & 156 & 178 & 113 & 90.4 & 76.7 & $2 \varnothing 25$ & 982 & 623 & 4.9 \\
\hline 24 & $\mathrm{~B} 92 \mathrm{C} 2$ & 151 & 179 & 108 & 90.4 & 76.7 & 2025 & 982 & 623 & 5.1 \\
\hline 25 & B92D1 & 155 & 185 & 118 & 47.5 & 42.1 & $2 \varnothing 16$ & 402 & 631 & 1.8 \\
\hline 26 & B92D2 & 151 & 181 & 116 & 47.5 & 42.1 & $2 \varnothing 16$ & 402 & 631 & 1.9 \\
\hline
\end{tabular}

Table 2. Concrete mix proportions of test beams

\begin{tabular}{|l|c|c|c|c|c|c|c|c|c|c|}
\hline Mix components & Unit & $\begin{array}{l}\text { B90A11 } \\
\text { B90A12 }\end{array}$ & $\begin{array}{l}\text { B90A15 } \\
\text { B90A16 }\end{array}$ & $\begin{array}{l}\text { B90A19 } \\
\text { B90A20 }\end{array}$ & $\begin{array}{l}\text { B91A1 } \\
\text { B91B3 }\end{array}$ & $\begin{array}{c}\text { B91A2 } \\
\text { B91A3 }\end{array}$ & $\begin{array}{c}\text { B91A4 } \\
\text { B91A5 } \\
\text { B91B4 } \\
\text { B91B5 }\end{array}$ & $\begin{array}{c}\text { B91B1 } \\
\text { B91B2 }\end{array}$ & $\begin{array}{c}\text { B92A1 } \\
\text { B92A2 } \\
\text { B92C1 } \\
\text { B92C2 }\end{array}$ & $\begin{array}{c}\text { B92B1 } \\
\text { B92B2 } \\
\text { B92D1 } \\
\text { B92D2 }\end{array}$ \\
\hline Portland cement, $c$ & $\mathrm{~kg} / \mathrm{m}^{3}$ & 499 & 510 & 411 & 450 & 450 & 400 & 450 & 429 & 430 \\
\hline Silica fume, $s$ & $\mathrm{~kg} / \mathrm{m}^{3}$ & 50 & - & 40 & 50 & 50 & 40 & 50 & 40 & - \\
\hline $\begin{array}{l}\text { Crushed aggr. } \\
8-18 \mathrm{~mm}\end{array}$ & $\mathrm{~kg} / \mathrm{m}^{3}$ & 905 & 860 & 990 & 1000 & 1000 & 940 & 1100 & 1070 & 805 \\
\hline Aggregate $0-8 \mathrm{~mm}$ & $\mathrm{~kg} / \mathrm{m}^{3}$ & 930 & 910 & 970 & 900 & 900 & 960 & 800 & 1030 & 865 \\
\hline Water, $w$ & $\mathrm{~kg} / \mathrm{m}^{3}$ & 131 & 181 & 119 & 152 & 164 & 153 & 128 & 148 & 176 \\
\hline Superplasticizer & $\mathrm{kg} / \mathrm{m}^{3}$ & 33 & - & 18.1 & 20 & 20 & 15 & 26 & 18.3 & - \\
\hline Retarder & $\mathrm{kg} / \mathrm{m}^{3}$ & 5.5 & - & 6.8 & 5 & 5 & 4 & 5 & 5.1 & - \\
\hline w/(c+s) & & 0.24 & 0.36 & 0.26 & 0.30 & 0.33 & 0.35 & 0.26 & 0.31 & 0.41 \\
\hline Age at beam test, $n$ & days & 21 & 19 & 21 & 23 & 21 & 28 & 28 & 28 & 28 \\
\hline
\end{tabular}


Table 3. Statistical parameters for relative curvatures, $\kappa_{t h} / \kappa_{\exp }$, estimated by different methods

\begin{tabular}{|c|c|c|c|c|c|c|c|c|c|}
\hline \multirow{2}{*}{ No. } & \multirow{2}{*}{$\begin{array}{c}\text { Characteristics of } \\
\text { data }\end{array}$} & \multicolumn{2}{|c|}{ ACI } & \multicolumn{2}{c|}{ EC2 } & \multicolumn{2}{c|}{ Russian Code } & \multicolumn{2}{c|}{ Present analysis } \\
\cline { 3 - 11 }$y$ & Mean & Stand. & Mean & Stand. & Mean & Stand. & Mean & Stand. \\
\hline 1. & $0.4 M_{u}$ (26 points) & 0.985 & 0.045 & 0.940 & 0.053 & 1.055 & 0.078 & 0.961 & 0.047 \\
\hline 2. & $0.6 M_{u}$ (26 points) & 0.938 & 0.053 & 0.904 & 0.066 & 1.080 & 0.089 & 0.935 & 0.055 \\
\hline 3. & $0.8 M_{u}$ (26 points) & 0.879 & 0.071 & 0.850 & 0.085 & 1.059 & 0.109 & 0.947 & 0.077 \\
\hline 4. & Total (130 points) & 0.935 & 0.066 & 0.900 & 0.075 & 1.069 & 0.092 & 0.944 & 0.059 \\
\hline
\end{tabular}

\section{Concluding remarks}

A simple iterative technique based on classical principles of strength of materials extended to layered approach and use of full material diagrams have been applied to curvature analysis of 26 high strength concrete beams. Comparison with the experimental curvatures at five load levels and with estimates of three other methods has been performed. Accuracy of predictions has been assessed using basic statistical parameters such as mean value and standard deviation calculated for relative curvatures. An excellent agreement for the total data has been achieved for the present analysis, Eurocode and $\mathrm{ACI}$ methods with standard deviations not exceeding $7.5 \%$ (Table 3). Even better results have been obtained for the moment level $0.4 M_{u}$, but greater variation corresponded to $0.8 M_{u}$. A tendency of the reduced mean value and its deviation from unity with increasing moments is clear for the ACI and Eurocode methods. Although predictions by the Russian Code method lead to a slightly greater standard deviation, the method gave a reasonable mean value.

The present analysis method as a universal, simple and accurate tool for deformation analysis of flexural reinforced concrete members can serve as an alternative to the code methods.

\section{References}

1. M. A. Mansur, M. S. Chin and T. H. Wee. Flexural Behavior of High-Strength Concrete Beams // ACI Structural Journal, V. 94, No 6, November-December, 1997, p. 663674

2. D. J. Careira and K. -H. Chu. Stress-Strain Relationship of Reinforced Concrete in Tension // ACI Journal, 83(1), 1986, p. 21-28.

3. E. Thorenfeldt, A. Tomaszewicz and J. J. Jensen. Mechanical Properties of High-Strength Concrete and Application in Design. Procedings, Sympozium in Stavanger, Norway, 1987, p. 17-22.

4. G. Kaklauskas. A New Stress-Strain Relationship for Cracked Tensile Concrete in Flexure // Statyba, Vol V, No 6. Vilnius: Technika, 1999, p. 349-356.
5. G. Kaklauskas. A Technique for Investigation of Tension Stiffening Effect of Flexural RC Members // Proceedings, 10th Nordic Seminar on Computational Mechanics, Tallinn, Estonia, October 24-25, 1997, p. 228-231.

6. G. Kaklauskas, J. Ghaboussi and X. Wu. Neural Network Modelling of Tension Stiffening Effect for R/C Flexural Members // Proceedings, EURO-C 1998-Computational Modelling of Concrete Structures, Badgastein, Austria, March 31 - April 3, 1998, p. 823-832.

7. G. Kaklauskas, D. Bačinskas, R. Šimkus. Deflection Estimates of Reinforced Concrete Beams by Different Methods // Statyba, Vol V, No 4. Vilnius: Technika, 1999, p. 258264.

8. M. Hallgren. Flexural and Shear Capacity of Reinforced High Strength Concrete Beams without Stirrups. Licentiate Thesis. Royal Institute of Technology, Stockholm, Sweden, 1994. $150 \mathrm{p}$

9. ACI Committee 318. Building Code Requirements for Reinforced Concrete and Commentary (ACI 318-89/ACI 318R-89). Detroit: American Concrete Institute (ACI), 1989. $353 \mathrm{p}$.

10. ENV 1992-1-1.Eurocode 2: Design of Concrete Structures Part 1: General rules and rules for buildings. Brussels, 1992. $114 \mathrm{p}$

11. СНиП 2.03.01-84*. Бетонные и железобетонные констружии. М.: Госстрой СССР. 1989.80 c.

Itteikta 19991027

\section{STIPRAUS BETONO GELŽBETONINIỤ SIJU KREIVIUY ANALIZE}

\section{G. Kaklauskas, M. Hallgren}

Santrauka

Straipsnyje pateikti stipraus betono gelžbetoninių sijų deformatyvumo tyrimo rezultatai. Darbą sudaro dvi dalys: eksperimentinè ir teorinè.

Eksperimentinèje dalyje pateikti antrojo autoriaus Karališkajame technologijos institute (Švedijoje) atliktų bandymų [8] rezuitatai. 26 laisvai atremtos gelžbetonines sijos buvo isbandytos trumpalaike apkrova - dviem koncentruotomis jëgomis. Betono $150 \mathrm{~mm}$ kubeliụ stipris kito nuo 40 iki $100 \mathrm{MPa}$. Staciakampio skerspjūvio sijos, grynojo lenkimo zonoje armuotos tik tempiama armatūra, buvo sudalytos $i$ tris serijas: B90, B91, B92. B90 serijos sijos buvo 4,0 m ilgio, o skerspjūvio aukštis $140 \mathrm{~mm}$, plotis $150 \mathrm{~mm}$. Atitinkami B91 ir B92 seriju siju nominalūs matmenys buvo $5,2 \mathrm{~m}, 150 \mathrm{~mm}$ ir $180 \mathrm{~mm}$. Sijų skerspjūvio ir betono mišinio charakteristikos pateiktos atitinkamai 1 ir 2 lentelèse. 
Siju gniuždomo betono deformacijos grynojo lenkimo zonoje buvo matuojamos penkiais $30 \mathrm{~mm}$ ilgio elektriniais tenzodavikliais, priklijuotais skirtinguose skerspjūvio aukščiuose. Armatūros strypu deformacijos buvo matuojamos $8 \mathrm{~mm}$ ilgio tenzodavikliais.

Teorineje dalyje eksperimentinems sijoms buvo apskaičiuoti kreiviai sluoksnių metodu ir palyginti su kitu žinomu analitinių metodų apskaičiavimo rezultatais. Skaičiuojant sluoksnių metodu, gelžbetoninio elemento skerspjūvis yra sudalijamas i horizontalius i betono ir armatūros sluoksnius. Skaičiuojama iteracijomis, taikant medžiagų atsparumo formules bei išsamias medžiagu diagramas. Gniuždomam betonui taikoma (1), o tempiamam betonui pirmojo autoriaus pasiūlyta (3) priklausomybè.

Kiekvienai sijai penkiuose apkrovos lygiuose $(0,4,0,5$, $0,6,0,7$ ir 0,8 eksperimentinio ardanciojo momento $M_{u}$ reikšmes) buvo apskaičiuoti kreiviai ir palyginti su eksperimentu rezultatais. Eksperimentines (punktyrine linija) ir teorinès (ištisa linija) momentų-kreivių diagramos visoms sijoms pateiktos 3 pav. Nors gautas neblogas teoriniu ir eksperimentinių kreivių atitikimas, daugeliui sijų, esant didesnems apkrovoms, apskaičiuoti kreiviai yra kiek mažesni už eksperimentinius. Tai matyti 4 pav., kuriame pateikta santykiniu kreiviu $\left(\kappa_{t h} / \kappa_{\exp }\right.$, kur $\kappa_{t h}$ yra teorinis, o $\kappa_{\exp }$ - eksperimentinis kreivis) priklausomybè nuo momento.

Be sluoksnių metodo, kreiviai dar buvo apskaičiuoti amerikietišku [9], Euronormu [10] bei Lietuvoje galiojančiu normu [11] metodais. Vertinant tiksluma kiekvienu skaičiavimo metodu nustatytiems santykiniams kreiviams buvo gauti tokie svarbiausi statistiniai dydžiai kaip vidurkis bei vidutinis kvadratinis nuokrypis. Statistinio apskaičiavimo rezultatai pateikti 3 lentelèje. Sluoksnių, Euronormu ir amerikietišku normų metodais apskaiciuotiems kreiviams vidutinis kvadratinis nuokrypis, nustatytas visiems eksperimento taškams (visos sijos, 5 apkrovos lygiai), neviršija 7,5\%. Apkrovos lygiui $0,4 M_{u}$ vidutinis kvadratinis nuokrypis dar mažesnis, tačiau jis yra didesnis apkrovos lygiui $0,8 M_{u}$. Reikia pažymèti, kad Euronormų ir amerikietiškụ normų metodams gauta kiek didesnè sisteminè paklaida nei sluoksniu metodui, ypač didesniems apkrovos lygiams. Lietuvoje galiojanciu normų metodui gauta sisteminè paklaida yra apytikriai tokia kaip kitu metodu, taciau vidutinis kvadratinis nuokrypis kiek didesnis. Apskritai imant, toks geras apskaičiuotų ir eksperimentinių kreivių sutapimas visiems metodams gali büti paaiškintas ne tik eksperimento kokybe, bet ir maža tempiamo betono įtaka šių stipriai armuotų siju deformatyvumui.

Gintaris KAKLAUSKAS. PhD, Senior Researcher and Associate Professor. Dept of Reinforced Concrete Structures, Vilnius Gediminas Technical University, Sauletekio al. 11, 2040 Vilnius, Lithuania.

Graduate of Vilnius Civil Engineering Institute (presently Vilnius Gediminas Technical University, VGTU), 1982 (civil engineer). PhD (1990). Research visits: Aalborg University (Denmark, 1991), University of Glamorgan (UK, 1994/1995, 1998), University of Illinois, Urbana-Champaign (USA, 1996). Author and co-author of 2 monographs, 1 invention and a number of papers. Research interests: development of constitutive relationships for concrete and numerical simulation of reinforced concrete structures.

Mikael HALLGREN. PhD, Structural Engineer, Head of Civil Engineering Department, Scandiaconsult, AB, PO Box 4205, SE-102 65 Stockholm, Sweden.

Graduate of the Royal Institute of Technology, MSc (civil engineering, 1989), (Licentiate of Eng. 1994), Doctor of Techn., PhD (1996). Author of 2 monographs, and author and co-author a number of papers and reports. Research interests: high strength concrete structures, flexural capacity, shear and punching shear, shock-wave loading, and numerical simulation of reinforced concrete structures. 